\title{
PENGARUH PROFITABILITAS, SOLVABILITAS,LIKUIDITAS, DAN INFLASI TERHADAP NILAI PERUSAHAAN
}

\author{
A.A.Ngr Bgs Aditya Permana ${ }^{1}$ \\ Henny Rahyuda ${ }^{2}$ \\ ${ }^{1,2}$ Fakultas Ekonomi dan Bisnis Universitas Udayana, Bali, Indonesia \\ e-mail:agungadityapermana.aa@gmail.com
}

\begin{abstract}
ABSTRAK
Tujuan penelitian ini untuk mengetahui signifikansi pengaruh profitabilitas, solvabilitas, likuiditas dan inflasi terhadap nilai perusahaanPenelitian ini dilakukan di perusahaan Manufaktur Sektor Logam yang terdaftar di Bursa Efek Indonesia (BEI) periode 2014 2016. Jumlah sampel penelitian ini adalah 16 perusahaan dengan metode sampling jenuh yaitu semua populasi dijadikan sampel. Pengumpulan data dilakukan dengan metode observasi non partisipan yaitu melalui data laporan keuangan yang dipublikasikan pada website www.idx.co.id.Berdasarkan hasil analisis ditemukan bahwa profitabilitas, solvabilitas, likuiditas, dan inflasi secara simultan berpengaruh signifikan terhadap nilai perusahaan. Profitabilitas dan inflasi secara parsial berpengaruh positif dan signifikan terhadap nilai perusahaan, Solvabilitas dan likuiditas secara parsial berpengaruh negatif terhadap nilai perusahaan.
\end{abstract}

Kata Kunci:profitabilitas, solvabilitas, likuiditas, inflasi, nilai perusahaan

\begin{abstract}
The purpose of this study was to determine the significance of the effect of profitability, solvency, liquidity and inflation on the value of the company. This research was conducted in the Metal Sector Manufacturing company listed on the Indonesia Stock Exchange (BEI) for the period of 2014-2016. The number of samples of this study were 16 companies with saturated sampling method, namely all populations were sampled. Data collection is carried out using non-participant observation methods, namely through financial report data published on the website www.idx.co.id. Based on the results of the analysis found that profitability, solvency, liquidity, and inflation simultaneously have a significant effect on firm value. Profitability and inflation partially have a positive and significant effect on firm value, Solvency and liquidity partially negatively affect the value of the company.
\end{abstract}

Keywords: profitability, solvency, liquidity, inflation, firm value 


\section{PENDAHULUAN}

Nilai perusahaan merupakan harga yang bersedia dibayar oleh calon pembeli apabila perusahaan tersebut dijual (Husnan dan Pudjiastuti,2013:277). Nilai perusahaan sangat penting karena mencerminkan kinerja perusahaan yang dapat mempengaruhi persepsi investor terhadap perusahaan. Nilai perusahaan yang tinggi akan membuat pasar percaya tentang keadaan perusahaan saat ini ataupun prospek perusahaan di masa depan (Wijaya, 2015). Bagi perusahaan yang mengeluarkan saham di pasar modal, harga saham yang diperjualbelikan di bursa merupakan indikator nilai perusahaan. Semakin tinggi harga saham suatu perusahaan semakin tinggi nilai perusahannya yang berdampak pada makin besarnya kemakmuran pemilik perusahaan. Nilai perusahaan dapat diukur menggunakan $P B V$ (Price Book Value)yaitu perbandingan antara harga pasar dan nilai buku saham (Husnan dan Pudjiastuti, 2013:258).

Nilai perusahaan akan tercermin dari harga sahamnya, harga pasar dari saham perusahaan yang terbentuk antara pembeli dan penjual disaat transaksi disebut nilai pasar perusahaan, karena harga pasar saham dianggap cerminan dari nilai aset perusahaan yang sesungguhnya.

Rata - rata harga saham pada tahun 2014 sebesar Rp.1219, tahun 2015 sebesar Rp.1250, dan tahun 2016 sebesar Rp. 964. hal ini menunjukan bahwa terjadi fluktuasi yang diakibatkan oleh beberapa faktor antara lain permintaan dan penawaran saham di BEI, perubahan perekonomian suatu negara, dan faktor intern perusahaan yang dapat mempengaruhi nilai perusahaan dapat berupa kinerja keuangan seperti aspek profitabilitas, likuiditas, solvabilitas. Menurut Sucipto (2003) kinerja keuangan adalah penentuan ukuran - ukuran tertentu yang 
dapat mengukur keberhasilan suatu organisasi atau perusahaan dalam menghasilkan laba.

Variabel internal yang mempengaruhi nilai perusahaan adalah besar kecilnya profitabilitas yang dihasilkan perusahaan (Jogiyanto,2013:121). Weston dan Copelan (2010:237), mendefenisikan sejauh mana perusahaan dapat menghasilkan laba dari penjualan dan investasi perusahaan. Peningkatan laba akan memberikan sinyal positif kepada investor bahwa perusahaan tersebut profitabledan diharapkan mampu memberikan kesahjetraan kepada pemegang saham melalui pengembalian saham yang tinggi. Profitabilitas dapat diukur menggunakan Return On Equity yaitu kemampuan perusahaan untuk menghasilkan laba menggunakan modal sendiri. Semakin tinggi nilai ROE maka semakin baik pula kondisi perusahaan, semakin besar pula penghasilan yang diperoleh perusahaan dan akan meningkatkan pula harga saham perusahaan yang bersangkutan sehingga dapat meningkatkan nilai perusahaan.Wiliam (2014) menemukan bahwa profitabilitas berpengaruh positif signifikan terhadap nilai perusahaan hal ini berarti profitabilitas dapat meningkatkan nilai perusahaan hal ini sependapat dengan penelitian yang dilakukan oleh Indah (2016), Ikbal dkk. (2011), Susanti (2010), Pakpahan (2010), Solihan dan Taswan (2002), Mahendra (2011) sedangkan penelitian yang dilakukan Gulton dan Syarif (2009), Susilowati (2011) serta Herawati (2012) mengemukakan hasil bahwa profitabilitas berpengaruh negatif terhadap nilai perusahaan.

Faktor selanjutnya yang mempengaruhi nilai perusahaan adalah solvabilitas atau berapa besar modal yang dibiayai mengunakan hutang untuk oprasional 
perusahaan.Wiagustini (2010:76) menyatakan bahwa solvabilitas dapat diartikan sebagai kemampuan suatu perusahaan untuk melunasi kewajiban finansial perusahaan baik dalam jangka pendek maupun dalam jangka panjang atau rasio yang mengukur sejauh mana perusahaan dibayarkan dengan hutang. Solvabilitas dapat diukur menggunakan Debt to Equity Ratio (DER) yaitu rasio yang digunakan untuk menilai hutang dengan ekuitas. Rasio ini dapat dihitung dengan membandingkan seluruh hutang termasuk hutang lancar dengan ekuitas, maka semakin besar DER maka akan semakin kecil laba yang akan dibagikan kepada pemegang saham, sehingga dapat menurunkan harga saham yang bersangkutan.Jadi pengelolaan solvabilitas sangatlah penting dalam oprasional perusahaan dapat menjadi suatu acuan dalam meningkatkan ataupun menurunkan nilai perusahaan. Perusahaan yang memiliki hutang yang tinggiakan membuat investor enggan untuk melakukan investasi karena memiliki risiko untuk bangkrut yang lebih tinggi hal ini disebabkan oleh modal yang dimiliki perusahaan tidak lebih besar dibandingkan dengan hutang yang dimiliki. Penelitian oleh Kodongo dan Makoteli (2014), Mulyani (2017), Taurisina (2016)menemukan bahwa solvabilitasberpengaruh negatif terhadap nilai perusahaan, sedangkan Winarto (2015), Cheng dan Tzeng (2011) serta Siahaan (2012) menunjukan bahwa solvabilitas (DER) berpengaruh positif signifikan terhadap nilai perusahaan

Likuiditas memberikan gambaran tentang kemampuan perusahaan dalam memenuhi kewajiban - kewajiban jangka pendeknya (Wiagustini,2010:76). Semakin besar likuiditas maka perusahaan semakin mampu melunasi kewajibannya sehingga perputaran kas didalam perusahaan sangat baik dan dapat 
memberikan persepsi positif terhadap kondisi perusahaan. Likuiditas dapat dihitung menggunakan Curent Ratio $(C R)$ yaitu dengan cara membagi aktiva lancar dengan kewajiban lancar. Penelitian yang dilakukan oleh Putra (2016), Mahendra (2012), dan Prisilia (2013) mendapatkan hasil likuiditas berpengaruh positif signifikan terhadap nilai perusahaan sedangkan penelitian yang dilakukan oleh Pasaribu dan Rowland (2008), Rompas dan Gisela (2013), Nurhayati (2013) mengemukakan bahwa likuiditas berpengaruh negatif terhadap nilai perusahaan.

Salah satu faktor eksternal perusahan yang dapat mempengaruhi nilai adalah inflasi yang terjadi pada suatu negara. Inflasi merupakan kecenderungan hargaharga untuk meningkat secara umum dan terus menerus (Nopirin,2010:27). Adaanya kenaikan harga mengakibatkan daya beli masyrakat menurun karena masyarakat akan lebih memilih menyimpan dana yang dimillikinya karena bunga yang ditawarkan lebih tinggi dibandingkan tingkat pengembalian dari investasi saham. Dampak yang diberikan kepada nilai perusahaan akan terlihat pada saat terjadinya jual/beli di Bursa Efek Indonesia dimana investor akan menurunkan daya beli terhadap saham dengan demikian akan secara langsung mempengaruhi nilai perusahaan karena nilai saham merupakan ceriminan dari nilai perusahaan. Penelitian yang dilakukan oleh Putra dkk. (2016), Suramaya (2012), Witha (2012) menemukan hasil bahwa inflasi berpengaruh negatif terhadap nilai perusahaan hal ini tidak senada dengan penelitian yang dilakukan oleh Purnomo (2013), Suryati (2015), Merindha (2016) yang menemukan hasil bahwa inflasi berpengaruh positif tidak signifikan terhadap nilai perusahaan. 
Perkembangan industri sektor logam akan selalu berkembang pesat dan meningkat tiap tahunnya, itu dikarenakan adanya permintaan bahan logam yang tinggi serta pengembangan infrastruktur yang terus dilakukan oleh pemerintah.Industri logam dan sejenisnya merupakan salah satu sub sektor perusahaan manufaktur pada sektor industri dasar dan kimia yang merupakan sektor bidang manufaktur yang tergolong membutuhkan dana yang tidak sedikit dikarenakan di dalam industri ini dibutuhkan berbagai macam teknologi untuk mendukung produktivitas perusahaan. Keadaan Perusahaan Manufaktur yang terdaftar di BEI dapat digambarkan ke dalam Indeks Tendensi Bisnis yang dipublikasikan oleh kementrian perdagangan.

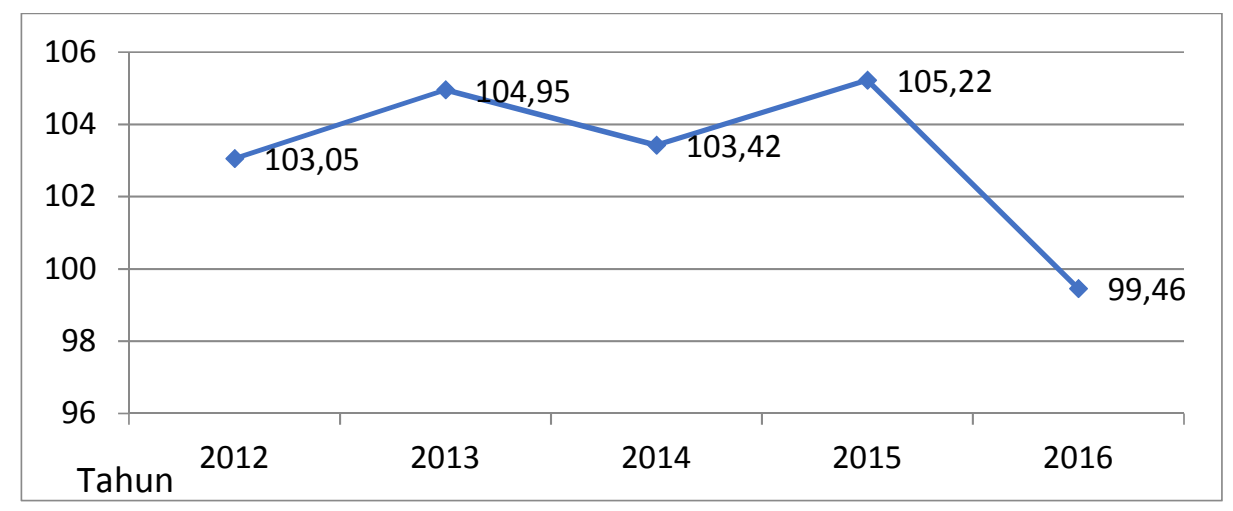

\section{Gambar 2. Indeks Tendensi Bisnis Manufaktur Sektor Logam Periode 2012 - 2016}

Sumber:www.kemenperin.co.id, 2017

Pertumbuhan industri sektor loham mengalami fluktuasi selama periode 2014-2016, dimana pada kuartal pertama tahun 2014 nilai ITB (Indeks Tendensi Bisnis) berada pada nilai 101,95 kemudian pada kuartal ketiga tahun 2014 mengalami penurunan dari nilai 107,24 menjadi 103.42 pada kuartal pertama 2015, nilai tertinggi diperoleh pada kuartal pertama tahun 2016 sebesar 110.24 tetapi mengalami penurunan kembali pada kuartal terakhir tahun 2016. Hal 
tersebut diakibatkan oleh berbagai faktor yang mempengaruhi niat investor untuk berinvestasi seperti faktor intern dan ekstern perusahaan.

Nilai perusahaan adalah persepsi investor terhadap tingkat keberhasilan perusahaan yang sering dikaitkan dengan harga saham. Harga saham yang tinggi membuat nilai perusahaan juga tinggi, dan meningkatkan kepercayaan pasar tidak hanya terhadap kinerja perusahaan saat ini namun juga pada prospek perusahaan di masa mendatang. Memaksimalkan nilai perusahaan sangat penting artinya bagi suatu perusahaan, karena dengan memaksimalkan nilai perusahaan berarti juga memaksimalkan tujuan utama perusahaan. Meningkatnya nilai perusahaan adalah sebuah prestasi yang sesuai dengan keinginan para pemiliknya, karena dengan meningkatnya nilai perusahaan, maka kesejahteraan para pemilik juga akan meningkat.

Nilai perusahaan dapat diukur dengan menggunakan harga saham menggunakan rasio yang disebut rasio penilaian. Menurut Sudana (2011:23), rasio Penilaian adalah suatu rasio yang terkait dengan penilaian kinerja saham perusahaan yang telah diperdagangkan di pasar modal (go public). Rasio penilaian memberikan informasi seberapa besar masyarakat menghargai perusahaan, sehingga masyarakat tertarik untuk membeli saham dengan harga yang lebih tinggi dibanding nilai bukunya.Berikut ini beberapa metode yang digunakan untuk mengukur nilai perusahaan.

Rasio profitabilitas merupakan rasio untuk menilai kemampuan perusahaan dalam mencari keuntungan.Rasio ini juga memberikan ukuran perusahaan dalam mencari keuntungan.Rasio ini juga memberikan ukuran tingkat efektivitas 
manajemen suatu perusahaan.Hal ini ditunnjukan oleh laba yang dihasilkan dari penjualan dan pendapatan investasi (Kasmir, 2013:196).

Kegunaan rasio profitabilitas dapat dilakukan dengan menggunakan perbandingan antara berbagai komponen yang ada dilaporan keuangan, terutama laporan keuangan neraca dan laporan laba rugi. Pengukuran dapat dilakukan untuk beberapa periode operasi. Tujuannya adalah agar terlihat perkembangan perusahaan dalam centang waktu tertentu, baik penurunan atau kenaikan, sekaligus mencari penyebab perubahan tersebut (Kasmir,2013:196).

Salah satu faktor penting dalam unsur pendanaan adalah hutang (leverage).Solvabilitas merupakan ukuran yang memperlihatkan sejauh mana perusahaan dapat membiayai oprasionalnya mengunakan pembiayaan utang (total hutang) dalam struktur modal perusahaan untuk membiayai kegiatan perusahaan (Brigham dan Houston, 2013:142). Solvabilitas dapat dipahami sebagai bagian dari risiko yang melekat pada perusahaan. Artinya, Solvabilitas yang semakin besar menunjukkan resiko investasi yang semakin besar pula. Perusahaan yang dengan rasio yang rendah memiliki risiko solvabilitas yang lebih kecil.

Likuiditas merupakan kemampuan perusahaan untuk memenuhi kewajiban finansialnya dalam jangka pendek dengan dana lancar yang tersedia (Wiagustini, 2010:76). Tingkat likuiditas yang tinggi berarti perusahaan tersebut semakin likuid dan semakin besar kemampuan perusahaan untuk melunasi kewajiban financial jangka pendeknya, hal tersebut baik bagi perusahaan agar tidak dilikuidasi akibat ketidakmampuan perusahaan dalam membayar kewajiban jangka pendeknya seperti pembayaran gaji karyawan, biaya oprasional. 
Menurut Gregory et al. (2012). Inflasi merupakan keadaan dimana adanya peredaran uang yang terlalu tinggi di masyarakat sehingga menurunkan nilai nominal uang tersebut. Ada beberapa hal yang dapat mempengaruhi tingkat inflasi diantaranya adalah jumlah uang yang beredar, permintaan uang dan keseimbangan moneter.Jenis inflasi menurut sifatnya: 1) Creeping inflation adalah inflasi yang ditandai dengan kenaikan harga yang lambat, dengan persentase yang kecil serta dalam jangka yang relatif lama. Laju inflasi rendah (kurang dari 10\% pertahun). 2) Galloping inflation adalah inflasi yang ditandai dengan kenaikan harga yang cukup besar (biasanya double digit atau bahkan triple digit) dan kadang kala berjalan dalam waktu yang relatif pendek serta mempunyai sifat akselerasi. Artinya harga-harga minggu/bulan ini lebih tinggi dari minggu/bulan lalu dan seterusnya.3) Hiper inflation merupakan inflasi yang paling parah akibatnya. Harga-harga naik sampai 5 atau 6 kali. Masyarakat tidak lagi berkeinginan untuk menyimpan uang. Nilai uang merosot dengan tajam, perputaran uang makin cepat, harga naik secara akselerasi. Biasanya keadaan ini timbul apabila pemerintah mengalami deficit anggaran belanja (misalnya ditimbulkan oleh adanya perang) yang dibelanjai/ditutup dengan mencetak uang.

Wiagustini (2010:76) menyatakan bahwa profitabilitas menunjukkan keberhasilan suatu perusahaan untuk memperoleh keuntungan.Profitabilitas merupakan salah satu yang dapat mempengaruhi nilai perusahaan.Profitabilitas dapat dihitung dengan return on equity (ROE).Return On Equity mencerminkan tingkat hasil pengembalian investasi bagi pemegang saham. Profitabilitas yang tinggi mencerminkan kemampuan perusahaan dalam menghasilkan keuntungan 
yang tinggi bagi pemegang saham. Dengan rasio profitabilitas yang tinggi yang dimiliki oleh perushaan akan menarik minat investor untuk menanamkan modalnya diperusahaan. Tingginya minat investor untuk menanamkan modalnya pada perusahaan dengan ROE yang tinggi akan meningkatkan harga saham (Kusumawati,2005). Hubungan positif antara profitabilitas dengan harga saham dimana tingginya harga saham akan mempengaruhi niat investor untuk berinvestasi karena harga saham merupakan reflikasi dari nilai perusahaan.

Hasil penelitian dari Yianis et al. (2003) menemukan bahwa profitabilitas berpengaruh positif signifikan terhadap nilai perusahaan,hasil penelitian yang sama juga dikemukakan oleh Matraves dan Rodriguez (2005), Suryakanta (2017), Martinez et al. (2013), Purwanto (2017), Indah Sari (2016), Ikbal dkk. (2011), Susanti (2010), Pakpahan (2010), Solihan dan Taswan (2002), Mahendra DJ (2011).

$\mathrm{H}_{1}$ :Profitabilitas berpengaruh positif signifikan terhadap nilai perusahaan

Sebuah perusahaan dikatakan insolvable apabila total hutang perusahaan lebih besar dari pada total aset yang dimiliki perusahaan, semakin tingginya aspek solvabilitasmenunjukan semakin besarnya dana yang disediakan oleh kreditur (Hanafi,2011:36). Hal tersebut akan membuat investor berhati - hati untuk berinvestasi di perusahaan yang memiliki solvabilitas yang tinggi karena semakin tinggi rasio solvabilitas semakin tinggi pula risiko investasinya keputusan dalam penggunaan hutang yang tinggi dapat menaikan risiko kebangkrutan jika perusahaan tidak mampu membayar hutang tersebut (Weston dan Copeland,2010:245). Penelitian Sudiyatno (2012) mengatakan bahwa solvabilitas 
memiliki hubungan yang negatif signifikan terhadap nilai perusahaan pada 30 perusahaan manufaktur yang terdaftar di bursa efek Indonesia, hal tersebut senada dengan penelitian yang dilakukan oleh Malkoteli (2014) dan Mulyani (2017) yang menemukan hasil bahwa solvabilitas berpengaruh negatif pada nilai perusahaan.

$\mathrm{H}_{2}$ :Solvabilitas berpengaruh negatif signifikan terhadap nilai perusahaan

Likuiditas dapat dikatakan sebagai salah satu faktor yang digunakan untuk mengukur kemampuan perusahaan membayar kewajiban - kewajiban yang harus diselesaikan, hal tersebut akan memberikan dampak besar pada nilai perusahaan di hadapan para investor dalam mengambil keputusan karena tingkat likuiditas yang tinggi menunjukan bahwa perusahaan mampu membayar seluruh kewajiban yang dimiliki baik jangka pendek maupun panjang. Investor akan menilai bahwa perusahaan yang memiliki likuiditas yang tinggi mampu mengelola perputaran kas, perputaran kas yang baik mengindikasikan bahwa perusahaan tersebut lancar/liquid.Penelitian yang dilakukan Winarto (2015) menemukan bahwa likuiditas berpengaruh positif terhadap nilai perusahaan pada penelitian yang dilakukan 32 perusahaan manufaktur yang terdaftar di bursa efek Indonesia periode 2005 - 2010, penelitian yang sama juga didapatkan oleh Putra dan Lestari(2016), Saini (2009), Anzlina (2013), Ainun (2016) dan Maryani (2016) menemukan bahwa likuiditas berpengaruh Positif signifikan terhadap nilai perushaan pada perusahaan manufaktur yang terdaftar di bursa efek Indonesia periode 2010 - 2013.

$\mathrm{H}_{3}$ :Likuiditas berpengaruh positif signifikan terhadap nilai perusahaan 
Menurut Rahardja dan Manurung (2008:165) inflasi adalah kenaikan harga barang-barangyang bersifat umum dan terus menerus.Inflasi yang meningkat berdampak terhadap penurunan penjualan, yang menyebabkan investor tidak mampu dalam melakukan investasi dikarenakan investor akan lebih memilih menyimpan dana yang mereka miliki di bank sebab bunga yang ditawarkan lebih tinggi dibandingkan tingkat pengembalian dari investasi saham, penurunan permintaan saham mengakibatkan turunya harga saham yang tentunya berpengaruh terhadap nilai perusahaan. Hasil penelitian yang dilakukan oleh Purnomo dan Widyawati (2013) yang mendapatkan hasil bahwa inflasi berpengaruh positif terhadap nilai perusahaan pada perusahaan sektor properti pada periode 2010-2012, begitu juga penelitian yang dilakukan Hamidah et al. (2015), Noerirawan (2012).

$\mathrm{H}_{4}$ : Inflasi berpengaruh negatif signifikan terhadap nilai perusahaan

\section{METODE PENELITIAN}

Lokasi penelitian ini dilakukan di perusahaan manufaktur sektor logam yang terdaftar di Bursa Efek Indonesia periode 2014 - 2016 dengan mengakses www.idx.co.id.Objek penelitian ini adalah nilai perusahaan yang dipengaruhi oleh profitabilitas, solvabilitas, likuiditas dan inflasi pada perusahaan manufaktur sektor logam yang terdaftar di Bursa Efek Indonesia periode 2014 - 2016.

Satuan pengukuran return on equity(ROE) adalah persentase (\%) pada perusahaan manufaktur sektor Logam yang terdaftar di Bursa Efek Indonesia (BEI) Periode 2014 - 2016.

$$
R=\frac{\text { Laba bersih setelah pajak }}{\text { Modal sendiri }} \times 100 \%
$$


Satuan pengukuran rasiosolvabilitasadalah persentase $(\%)$ pada perusahaan manufaktur sektor logam yang terdaftar di Bursa Efek Indonesia (BEI) Periode 2014 - 2016 dan dirumuskan sebagai berikut :

$$
D=\frac{T}{T \quad M} \times 100 \%
$$

Satuan pengukuran current ratio (CR) adalah persentase (\%) pada perusahaan manufaktur sektor logam yang terdaftar di Bursa Efek Indonesia (BEI) Periode 2014 - 2016 dan dirumuskan sebagai berikut:

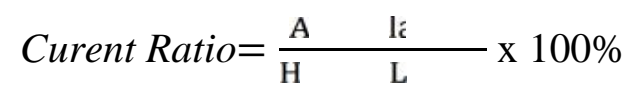

Inflasi adalah perubahan harga - harga barang terjadi secara terus menerus yang tercatat di Bank Indonesia periode 2014 - 2016yang diukur menggunakan satuan persentase (\%) dan dipubikasikan dalam bentuk tabel pada website www.bi.co.id.

Satuan pengukuran Price to Book Value dapat dihitung menggunakan satuan persentase $(\%)$ pada perusahaan manufaktur sektor logam yang terdaftar di Bursa Efek Indonesia (BEI) Periode 2014 - 2016. Rumus PBV sebagai berikut :

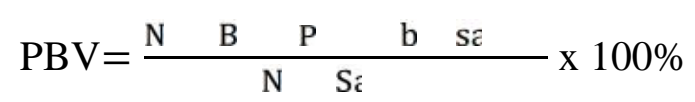

Populasi dalam penelitian ini adalah seluruh perusahaan manufaktur sub sektor logam dan sejenisnya yang terdapat di Bursa Efek Indonesia periode 20142016 dengan jumlah populasi sebanyak 16 perusahaan manufaktur. Pemilihan sampel penelitian ini dilakukan dengan mengunakan metode sampling jenuh (sampling sensus). 
Metode yang digunakan dalam penelitian ini adalah metode observasi non participant, metode ini dilakukan dikarenakan peneliti tidak terlibat langsung dalam aktivitas yang diteliti melainkan hanya memposisikan diri sebagai pengamat yaitu dengan melakukan observasi terhadap dokumen atau laporan keuangan perusahaan pada Perusahaan Manufaktur Sektor Logam yang terdaftar di Bursa Efek Indonesia (BEI) periode 2014 - 2016 yang dipublikasikan pada website www.idx.co.id

Analisis regresi linier berganda digunakan dalam penelitian ini untuk mengetahui pengaruh variabel independen terhadap variabel dependen. Dalam hal ini yang menjadi variabel bebas adalah Profitabilitas $\left(\mathrm{X}_{1}\right)$,Solvabilitas $\left(\mathrm{X}_{2}\right)$, Likuiditas $\left(\mathrm{X}_{3}\right)$ dan Inflasi $\left(\mathrm{X}_{4}\right)$, sedangkan variabel terikatnya adalah Nilai Perusahaan (Y).

Persamaan regresi linier berganda ini dirumuskan sebagai berikut :

$$
\mathrm{Y}=\mathrm{a}+\mathrm{b}_{1} \mathrm{X}_{1}+\mathrm{b}_{2} \mathrm{X}_{2}+\mathrm{b}_{3} \mathrm{X}_{3}+\mathrm{e}
$$

Keterangan :

$\mathrm{Y}=$ Nilai Perusahaan

$\mathrm{X}_{1} \quad=$ Profitabilitas

$\mathrm{X}_{2} \quad=$ Solvabilitas

$\mathrm{X}_{3}=$ Likuiditas

$\mathrm{X}_{4}=$ Inflasi

$\mathrm{a}=$ konstanta

$\mathrm{b}_{1}=\mathrm{b}_{2}=\mathrm{b}_{3}=\mathrm{b}_{4}=$ arah garis regresi yang menyatakan perubahan nilai $\mathrm{Y}$ akibat perubahan 1 unit $\mathrm{X}$ (koefisien regresi masing masing $\mathrm{Xi}$ )

$\mathrm{e} \quad=$ Variabel Pengganggu (Residual Eror)

\section{HASIL PENELITIAN DAN PEMBAHASAN}

Penelitian ini dilakukan pada perusahaan manufaktur sektor logam yang tedaftar di Bursa Efek Indonesia (BEI) periode 2014 - 2016. Jumlah perusahaan pada periode ini sebanyak 16 perusahaan, yaitu: PT. Alakasa Industrindo Tbk, PT. Alumindo Light Metal Industry Tbk, PT. Saranacentral Bajatama Tbk, PT. Beton 
Jaya Manunggal Tbk, PT. Citra Turbindo Tbk, PT. Gunawan Dianjaya Steel Tbk, PT. Indal Aluminium Industry Tbk, PT. Steel Pipe Industry of Indonesia Tbk, PT. Jakarta Kyoei Steel Work LTD Tbk, PT. Jaya Pari Steel Tbk, PT. Krakatau Steel Tbk, PT. Lion Metal Works Tbk, PT. Lionmesh Prima Tbk, PT. Pelat Timah Nusantara Tbk, PT. Pelangi Indah Canindo Tbk, PT. Tembaga Mulia Semanan Tbk.

PT. Alumnindo Light Metal (ALMI) beroperasi sebagai produsen lembaran aluminium. ALMI didirikan sebagai salah satu Grup Maspion, perusahaan pembuat peralatan dapur yang berpusat di Surabaya, Jawa Timur, Indonesia. Tujuan Awal ALMI adalah untuk memproduksi lembaran aluminium untuk mendukung produksi Groip Maspion didalam memenuhi pertumbuhan permintaan di Indonesiauntuk produk konsumen tahan lama berkualitas dan aluminium foil untuk industri kemasan. Produk lembaran aluminium umumnya digunakan untuk perlatan rumah tangga, peralatan listrik dan bahan konstruksi

PT. Saranacentral Bajatama Tbk. (BAJA) Beroperasi di industry baja lembaran galvanis sejak tahun 1966. Kantor pusat BAJA terletak di Jakarta dan pabriknya terletak di Karawang Timur, Indonesia.BAJA tercatat pada Bursa Efek Indonesia di tahun 2011 pada papan pengembangan.

PT. Beton Jaya Manunggal Tbk. (BTON) Bergerak di bidang produksi dan perdagangan batang besi untuk beton dan mulai beroprasi secara komersial pada mei 1996. BTON adalah produsen nasional bar bulat.Dalam hal aktivitas pemasaran, BTON mengoptimalkan jaringan distributor dan pelayanan langsung bagi calon pelanggan domestik.BTON tercatat di BursaEfek Indonesia di tahun 
2001 pada papan pengembangan.Perusahaan didirikan pada tahun 1995 dan berpusat di Gresik, jawa Timur, Indonesia.

PT. Citra Turbindo Tbk. (CTBN) beroperasi dipidang manufaktur dan penyediaan layanan untuk barang tubular lading minyak.Lebih dari $75 \%$ dari produk perusahaan dikirim kepada perusahaan minyak multinasional serta perusahaan minyak Negara yang terletak diseluruh dunia. Pabrik CTBN mulai berproduksi pada tahun 1984 sebagai sebuah perusahaan perintis di pulau batam, terletak hanya $20 \mathrm{~km}$ selatandari singapura dan sekarang telah menjadi pusat logistik untuk industry jasa minyak di seluruh Indonesia.

PT. Gunawan Dianjaya Steel Tbk. (GDST) Beroperasi dalam produksi pelat baja panas.Produk GDST digunakan dalam pembangunan kapal, alat berat dan konstruksi. GDST mengekspor produknya ke Australia, Timur Tengah, Eropa, Kanada dan di Negara -negara asia lainya. GDST tercatat di Bursa Efek Indonesia di tahun 2009 pada papan pengembangan.Perusahaan didirikan pada tahun 1989 dan berpusat di Surabaya, Jawa Timur, Indonesia.

PT, Indal Aluminium Industri Tbl. (INAI) Bergerak dalam bidang pembuatan produk aluminium.INAI yang merupakan anggota dari Group Maspion, mengoprasikan dua pabrik di Sidoarj, Jawa Timur. Kegiatan usaha INAI melibatkan pengelolahan aluminium bilet untuk profil aluminium yang biasanya digunakan dalam industry konstruksi, komponen elektronik dan otomotif peralatan rumah tannga dan sejenisnya.INAI tercatat di Bursa Efek Indonesia di tahun 1994 pada papan pengembangan. Perusahaan didirikan pada tahun 1971 dan berpusat di Sidoarjo, Jawa Timur Indonesia. 
PT. Steel Pipe Industry if Indonesia Tbk. (ISSP) Memproduksi berbagai macam pipa/ tabung baja. ISSP tercatat pada Bursa Efek Indonesia di tahun 2013 pada papan utama.Perusahaan didirikan pada tahun 1971 dan berpusat di Surabaya, Jawa Timur, Indonesia.

PT Jakarta Kyoei Steel Work LTD Tbk. (JKSW) beroperasi dibidang manufaktur dan perdagangan bar baja bulat polos, bar baja bulat cengkong dan batang kawat.Pabrik JKSW terletak di pulo gadung industrial estate, Jakarta.Pabriknya dilengkapi dengan fasilitas seperti tungku pemanasan ulang dan penggiling.Perusahaan didirikan sebagai perusahaan patungan antara dua perusahaan jepang, Kyeoi Steel Ltd. Dan Cltoh \& Co Ltd dan PT. Bone Comercial Indonesia.JKSW tercatat di Bursa Efek Indonesia di tahun 1997 pada papan pengembangan.

PT. Jaya Pari Steel Tbk. (JPRS) beroperasi dalam industry pemotongan kumparan gulung panas dan produsen pelat baja. JPRS telah menerima berbagai sertifikasi untuk industry baja, seperti sfesifikasi produk baja dari Biro Klasifikasi Indonesia dan Lloyd Register of Shipping. JPRS tercatat di Bursa Efek Indonesia di tahun 1989 pada papan pengembangan.Perusahaan didirikan pada tahun 1973 dan berpusat di Surabaya, Jawa Timur Indonesia.

PT. Krakatau Steel Tbk. (KRAS) merupakan Badan Usaha Milik Negara (BUMN) yang bergerak di sektor pertambangan bijih besi, batubara, mineral, pengolahan bahan mentah untuk besi.Perusahaan mulai beroperasi komersial pada tahun 1971. KRAS didirikan pada tahun 1971 dan berkantor pusat di Cilegon, 
Banten, Indonesia . Perusahaan tercatat pada Bursa Efek Indonesia di tahun 2010 pada papan utama

PT. Lion Metal Works Tbk. (LION) beroperasi dalam produksi peralatan kantor baja, peralatan gudang, bahan bangunan, peralatan rumah sakit dan keamanan tinggi dan produk baja lainnya dibuat. LION tercatat di Bursa Efek Indonesia pada tahun 1993 pada papan utama.Perusahaan didirikan pada tahun 1972 dan berpusat di Jakarta, Indonesia.

PT. Lionmesh Prima Tbk. (LMSH) beoperasi dalam produksi kawat las dalam berbagai ukuran dan dimensi.Produk ini terbentuk dalam lembaran atau gulungan, dibedakan dalam jarak mereka dari kabel lintas dan kabel line serta panjang dan lebar dari kabel.LMSH terdaftar di Bursa Efek Indonesia di tahun 1990 pada papan pengembangan.Perusahaan didirikan pada tahun 1982 dan berpusat di Jakarta, Indonesia.

PT. Pelat Timah Nusantara Tbk. (NIKL) beroperasi pada produksi tinplates. Produk NIKL digunakan dalam pembuatan makanan kaleng, susukaleng dan cat kaleng. Nippon Steel \& Sumitomo Metal Corporation Jepang merupakan penyedia utama bahan baku untuk NIKL, Tin Mill Hitam Plate (TMBP). NIKL tercatat di Bursa Efek Indonesia di tahun 2009 pada papan utama.Perusahaan didirikan pada tahun 1982 dan berpusat di Jakarta Indonesia.

PT. Pelangi Indah Canindo Tbk. (PICO) beroperasi sebagai produsen pengemasan metal diindonesia untuk bermacam produk drum, tabung LPJ, kaleng pail, kaleng makanan dan kemasan kaleng untuk memenuhi kebutuhan industri dan konsumen umum. PICO tercatat di Bursa Efek Indonesia di tahun 1996 pada 
papam pengembangan perusahaan didirikan pada tahun 1983 dan berpusat Jakarta Indonesia.

PT. Tembaga Mulia Semanan Tbk. (TBMS) beroperasi dalam pembuatan batang tembaga, kabel tembaga, batang aluminium dan kabel aluminium. TBMS juga memproduksi kawat tarik, kawat tembaga kaleng dan kabel serat optik. TBMS tercatat di Bursa Efek Indonesia di tahun 1993 pada papan pengembangan perusahaan didirikan pada tahun 1977 dan berpusat di Jakarta Indonesia.

Tabel 1.

Analisis Deskriptif

\begin{tabular}{lrrrrr}
\hline & N & \multicolumn{1}{c}{ Minimum } & Maximum & \multicolumn{1}{c}{ Mean } & Std. Deviation \\
\hline ROE & 48 & $-20,00$ & 17,5 & 1,4807 & 7,46182 \\
DER & 48 & 17 & 266,00 & 59,1090 & 71,04905 \\
CR & 48 & 1,04 & 1.331 & 225,7190 & 182,07726 \\
Inflasi & 48 & 3,33 & 8,36 & 5,4433 & 1,37616 \\
PBV & 48 & $-10,10$ & 350,10 & 62,5007 & 35,88304 \\
Valid N (listwise) & 48 & & & & \\
\hline
\end{tabular}

Sumber:Data diolah, 2018

Dari Tabel 1 dapat dilihat hasil uji deskriptif. Nilai minimumReturn to Equity sebesar -20.00 dimiliki oleh PT. Pelat Timah Nusantara Tbk dan nilai maksimum sebesar 17.5 dimiliki oleh PT. Citra Turbindo Tbk. Nilai minimum Debt to Equity Ratio sebesar 0.17 dimiliki oleh PT. Lionmesh Prima Tbk dan nilai maksimum sebesar 266.00 dimiliki oleh PT. Jakarta Kyoei Steel Work LTD Tbk. Nilai minimum Curent Ratio sebesar 1.04 dimiliki oleh PT.Jayapari Steel Tbk dan nilai maksimum sebesar 1.331 juga dimiliki oleh PT. Jayapari Steel Tbk. Nilai minimum inflasi sebesar 3.33 terjadi pada bulan april 2016 sedangkan nilai maksimum sebesar 8.36 terjadi pada bulan desember 2014. Nilai minimum Price to Book Value sebesar -10.10 dimiliki oleh PT. Jakarta Kyoei Steel Work LTD 
Tbk dan nilai maksimum sebesar 351.10 dimiliki oleh PT. Tembaga Mulia Samanan Tbk.

Analisis regresi dilakukan untuk mengetahui bagaimana variabel dependen dapat diprediksi melalui variabel independen.Analisis regeresi yang digunakan dalam penelitian ini adalah analisis regresi linier berganda. Hasil SPSS dari analisis regersi linier bergandadapat dilihat pada tabel 2dibawah ini:

Tabel 2.

Analisis Regresi Linier Berganda

\begin{tabular}{|c|c|c|c|c|c|c|}
\hline \multirow[b]{2}{*}{ Mod } & & \multicolumn{2}{|c|}{$\begin{array}{c}\text { Unstandardized } \\
\text { Coefficients }\end{array}$} & $\begin{array}{l}\text { Standardized } \\
\text { Coefficients }\end{array}$ & \multirow[b]{2}{*}{$\mathbf{t}$} & \multirow[b]{2}{*}{ Sig. } \\
\hline & & B & Std. Error & Beta & & \\
\hline \multirow[t]{5}{*}{1} & (Constant) & 76,710 & 23,819 & & 3,221 & 003 \\
\hline & ROE & 1,679 & 699 & ,335 & 2,404 & ,021 \\
\hline & DER &,- 273 & ,091 &,- 421 & $-3,011$ & ,005 \\
\hline & CR &,- 069 & ,035 &,- 279 & $-1,974$ & ,056 \\
\hline & Inflasi & 5,489 & 3,999 & 189 & 1,373 & ,178 \\
\hline
\end{tabular}

Sumber: Data diolah, 2018

Berdasarkan table 2 diperoleh persamaan regresi sebagai berikut :

$$
\mathrm{Y}=76710+1,679 R O E-0,273 D E R-0,069 C R+5,489 \text { Inflasi }
$$

Nilai koefisien regresi variabel $R O E(\mathrm{X} 1)$ sebesar 1,679 nilai yang positif menunjukkan adanya hubungan searah antara nilai perusahaan dengan $R O E$, jikaROE meningkat sebesar satu satuan sementara variabel lainnyadiasumsikan konstan atau sama dengan nol, maka nilai perusahaan akan meningkat sebesar 1,679 .

Nilai koefisien regresi variabel $\operatorname{DER}\left(\mathrm{X}_{2}\right)$ sebesar $-0,273$ nilai yang negatif menunjukkan adanya hubungan yang berlawanan antara nilai perusahaan dengan $D E R$, jika $D E R$ meningkat sebesar satu satuan sementara variabel lainnya diasumsikan konstan atau sama dengan nol, maka nilai perusahaan akan menurun sebesar -0,273. Nilai koefisien regresi variabel $C R$ 
(X3) sebesar -0,069 nilai yang negatif menunjukkan adanya hubungan yang berlawanan antara nilai perusahaan dengan $C R$, jika $C R$ meningkat sebesar satu satuan sementara variabel lainnyadiasumsikan konstan atau smaa dengan nol, maka nilai perusahaan akan menurun $-0,069$.

Nilai koefisien regresi variabel inflasi (X4) sebesar 5,489 nilai yang positif menunjukkan adanya hubungan searah antara nilai perusahaan dengan inflasi, jika inflasi meningkat sebesar satu satuan sementara variabel lainnya diasumsikan konstan atau sama dengan nol, maka nilai perusahaan akan meningkat sebesar 5,489 .

Tabel 3.

Uji Kelayakan Model F

\begin{tabular}{llrrrrr}
\hline Model & \multicolumn{1}{c}{$\begin{array}{c}\text { Sum of } \\
\text { Squares }\end{array}$} & df & & Mean Square & \multicolumn{1}{c}{ F } & \multicolumn{1}{c}{ Sig. } \\
\hline 1 & Regression & 19961,133 & 4 & 4990,283 & 4,104 &, $008^{\text {b }}$ \\
& Residual & 44994,728 & 37 & 1216,074 & & \\
& Total & 64955,861 & 41 & & & \\
\hline
\end{tabular}

Sumber: Data diolah, 2018

Dari table 3 diketahui nilai F hitung sebesar 4,104 > F tabel 2,626 dan nilai signifikansi $0,008<0.05$ maka hipotesis diterima. Hal ini berarti keempat variabel independent $R O E, D E R, C R$, Inflasi secara simultan berpengaruh signifikan terhadap variabel dependent yaitu nilai perusahaan.

Tabel 4.

Koefesien Determinasi

\begin{tabular}{lrrrrr}
\hline Model & R & R Square & Adjusted R Square & \multicolumn{2}{c}{$\begin{array}{c}\text { Std. Error of the } \\
\text { Estimate }\end{array}$} \\
\hline 1 &, $554^{\mathrm{a}}$ &, 307 &, 232 & 34,87225 \\
\hline
\end{tabular}

Sumber: Data diolah, 2018

Dari Tabel 4 diketahui nilai koefisien determinasi (Adjusted $R$ Square) adalah sebesar 0,232 atau sebesar 23,2\% hal ini menunjukkan bahwa pengaruh variabel independen yaitu $R O E, D E R, C R$, dan Inflasi adalah sebesar 23,2\% 
terhadap variabel dependen yaitu nilai perusahaan dan sisanya $76,8 \%$ dipengaruhi oleh variabel lain yang tidak termasuk dalam model penelitian ini.

Hasil penelitian ini menunjukan bahwa profitabilitas berpengaruh positif signifikan terhadap nilai perusahaan sehingga $\mathrm{H}_{1}$ diterima.Hal ini berarti bahwa apabila profitabilitas semakin meningkat maka nilai perusahaan tersebut juga akan meningkat, Saidi (2004) menyatakan semakin tinggi kemampuan perusahaan memperoleh laba, maka semakin besar returnyang diharapkan investor, sehingga menjadikan nilai perusahaan menjadi lebih baik.

Sesuai dengan penelitian yang dilakukan oleh Suryakanta (2017) bahwa aspek profitabilitas merupakan salah satu aspek yang menjadi pertimbangan untuk melakukan investasi. Hal ini berarti semakin tinggi nilai profit yang didapat maka semakin tinggi nilai perusahaan. Profit yang tinggi akan memberikan indikasi prospek perusahaan yang baik sehingga dapat memicu investor untuk ikut meningkatkan permintaan saham dengan melakukan investasi.

Hasil penelitian ini sejalan dengan Purwanto (2017), Indah Sari (2016), Ikbal dkk. (2011), Susanti (2010), Pakpahan (2010), Solihan dan Taswan (2002), Mahendra DJ (2011) yang menegaskan bahwa profitabilitas memiliki pengaruh signifikan terhadap nilai perusahaan.

Hasil penelitian ini menunjukan bahwa solvabilitas berpengaruh negatif signifikan terhadap nilai perusahaan sehingga $\mathrm{H}_{2}$ diterima. Hal ini menunjukan bahwa investor memperhatikan besarnya kewajiban atau hutang yang dimiliki perusahaan, jika aset yang dimiliki perusahaan tidak lebih besar dari hutang yang dimiliki maka perusahaan tersebut memiliki risiko yang lebih tinggi untuk 
mengalami kebangkrutan karena semakin besar Debt to Equity Ratio (DER) maka semakin besar komposisi hutang sehingga berdampak semakin besar beban perusahaan terhadap pihak luar (Kreditur).

Meningkatnya beban terhadap kreditur menunjukan sumber modal perusahaan sangat tergantung dengan pihak luar. Selain itu besarnya beban hutang yang ditanggung perusahaan dapat mengurangi jumlah laba yang diterima perusahaan dikarenakan perusahaan akan berusaha untuk lebih membayar kewajiban yang dimiliki. Keuntungan perusahaan yang kecil akan berdampak pada tingkat pengembalian yang diberikan kepada pemegang saham. Investor akan mempertimbangkan kembali untuk melakukan investasi sehingga permintaan terhadap saham perusahaan akan menurun, dan pada akhirnya akan mempengaruhi nilai perusahaan.

Hasil penelitian ini sejalan dengan penelitian yang telah dilakukan oleh Sudiyatno (2012), Malkoteli (2014) dan Mulyani (2017) yang menemukan hasil bahwa solvabilitas berpengaruh negatif pada nilai perusahaan. Berdasarkan hasil penelitian yang dilakukan, ditemukan bahwa hipotesis ke tiga $\left(\mathrm{H}_{3}\right)$ ditolak dan dapat disimpulkan bahwa likuiditas berpengaruh negatif signifikan terhadap nilai perusahaan manufaktur sektor logam di Bursa Efek Indonesia (BEI). Sawir (2009:10) yang menyatakan bahwa Curent Ratio yang rendah menunjukkan terjadinya masalah dalam likuidasi, sebaliknya Curent Ratio yang terlalu tinggi juga kurang bagus karena menunjukkan banyaknya dana menganggur yang pada akhirnya dapat mengurangi kemampuan perusahaan untuk menghasilkan laba akibat perusahaan lebih memilih 
menggunakan uang berlebih tersebut untuk membayar kewajiban yang dimiliki dari pada membelikanya asset baru.

Keputusan perusahaan untuk membayar kewajiban yang tinggi akan mempengaruhi tingkat pengembalian kepada pemegang saham. Tingkat pengembalian yang kecil akan membuat para investor mempertimbangkan kembali keputusannya dalam melakukan investasi sehingga akan mempengaruhi nilai perusahaan.

Hasil penelitian ini konsisten dengan penelitian yang telah dilakukan oleh Pasaribu dan Rowland (2008), Rompas dan Gisela (2013), Nurhayati (2013) yang menegaskan bahwa likuiditas berpengaruh negatif signifikan terhadap nilai perusahaan.

Hasil penelitian ini menunjukan bahwa inflasi berpengaruh positif signifikan terhadap nilai perusahaan sehingga $\mathrm{H}_{4}$ ditolak. Hal ini dikarenakan inflasi yang terjadi pada periode penelitian tidak melebihi $10 \%$ sehingga kenaikan yang terjadi masih dikategorikan wajar oleh para investor.

Jenis Inflasi yang dapat mendukung hasil penelitian ini disebut Creeping Inflation yaitu inflasi yang ditandai dengan kenaikan harga yang lambat (kurang dari $10 \%$ pertahun), dengan presentase yang kecil serta dalam jangka yang relatif lama. Berdasarkan jenis inflasi tersebut investor akan lebih tertarik untuk melakukan investasi dikarenakan terjadinya ketidakseimbangan terhadap harga komoditi yang diperjualbelikan. Ketidakseimbangan tersebut memberikan tantangan kepada para investor untuk mengambil peluang keuntungan dari perubahan harga tersebut sehingga pergerakan kenaikan harga yang masih 
cinderung lamban tidak akan terlalu mempengaruhi investor dalam melakukan keputusan investasi.

Hasil penelitian tersebut senada dengan Purnomo (2013), Widyawati (2013) yang menemukan hasil bahwa inflasi berpengaruh positif signifikan terhadap nilai perusahaan.

Berdasarkan hasil penelitian ini, hanya profitabilitas dan inflasi yang berpengaruh positif signifikan terhadap nilai perusahaan.Hal ini dikarenakan profitabilitas yang tinggi mampu menunjukkan kondisi perusahaan yang baik sehingga mampu menarik minat investor untuk melakukan investasi, dan dampaknya dapat menaikan nilai perusahaan.Inflasi pada penelitian ini termasuk dalam kategori yang rendah yang berada dalam posisi dibawah $10 \%$. Inflasi dapat memberikan dampak kepada pengambilan keputusan investasi oleh para investor tetapi apabila inflasi tersebut berada dalam level yang rendah maka investor cinderung lebih tertarik melakukan investasi karena terjadinya ketidakseimbangan harga. Hal ini sesuai dengan penelitian yang dilakukan oleh Widyawati (2013).

Penelitian ini menghasilkan informasi bahwa solvabilitas dan likuiditas berpengaruh negatif terhadap nilai perusahaan yang berarti bahwa perusahaan yang memiliki solvabilitas yang tinggi memiliki resiko yang jauh lebih tinggi. Likuiditas yang terlalu tinggi juga dapat menghambat kemampuan perusahaan dalam menghasilkan laba dikarenakan banyaknya kas yang menganggur sehingga menurunkan produktivitas perusahaan dalam menghasilkan laba.

Dengan hasil penelitian ini diharapkan investor mendapat informasi tambahan yang berguna dalam pertimbangan keputusan berinvestasi dikarenakan 
kedua faktor internal tersebut merupakan hal yang sangat riskan berhubungan dengan nilai perusahaan. Nilai perusahaan yang tinggi memberikan persepsi kepada investor bahwa perusahaan tersebut dalam keadaan sehat sedangkan jika nilai perusahaan tersebut rendah dapat menandakan keadaan perusahaan yang kurang baik, sehingga investor akan lebih selektif dalam pengambilan keputusan.

\section{SIMPULAN DAN SARAN}

Berdasarkan hasil analisis data, pengujian hipotesis dan pembahasan, maka dapat ditarik kesimpulan bahwa hipotesis pertama menyatakan bahwa profitabilitas yang diproksikan dengan Return on Equity berpengaruh positif signifikan terhadap nilai perusahaan, sehingga $\mathrm{H}_{1}$ diterima. Karena pada penelitian ini ROE berpengaruh terhadap nilai perusahaan pada perusahaan manufaktur sektor logam yang terdaftar di BEI periode 2014 - 2016. Hipotesis kedua menyatakan bahwa Solvabilitas yang diproksikan dengan Debt to Equity Ratio berpengaruh negatif signifikan terhadap nilai perusahaan, sehingga $\mathrm{H}_{2}$ diterima. Karena pada penelitian ini DER berpengaruh negatif signifikan terhadap nilai perusahaan manufaktur sektor logam yang terdaftar di BEI periode 2014 - 2016. Hipotesis Ketiga menyatakan bahwa Likuiditas yang di proksikan dengan Curent Ratio berpengaruh negatif signifikan terhadap nilai perusahaan, sehingga $\mathrm{H}_{3}$ ditolak. Karena pada penelitian ini $\mathrm{CR}$ berpengaruh negatif terhadap nilai perusahaan manufaktur sektor logam yang terdaftar di BEI periode 2014 - 2016. Hipotesis Keempat menyatakan bahwa Inflasi berpengaruh positif signifikan terhadap nilai perusahaan. Hal ini berarti $\mathrm{H}_{4} \mathrm{di}$ tolak. 
Saran penelitian ini bagi perusahaan, disarankan agar lebih meningkatkan profitabilitas perusahaan karena dengan meningkatkan profitabilitas perusahaan maka juga akan meningkatkan nilai perusahaan, jika keuntungan meningkat maka akan menarik banyak investor untuk menanamkan modal di perusahaan sehingga harga saham akan ikut meningkat dan secara tidak lansung meningkatkan nilai perusahaan. Bagi peneliti selanjutnya agar tidak hanya menggunakan beberapa faktor fundamental dan faktor makro ekonomi sebagai variabel yang mempengaruhi nilai perusahaan, melainkan menggunakan semua aspek fundamental dan makro ekonomi seperti struktur modal, ukuran perusahaan, nilai kurs dan suku bungasebagai variabel tambahan dalam mempengaruhi nilai perusahaan. Bagi investor dapat menjadikan aspek keuangan sebagai alat ukur dan bahan pertimbangan untuk melakukan investasi agar dapat meminimalisir kerugian yang dialami saat mengambil keputusan investasi.

\section{REFERENSI}

AinunJariah. (2016).Likuiditas, Leverage, Profitabilitas pengaruhnya terhadap Nilai Perusahaan Manufaktur di Indonesia Melalui Kebijakan Deviden. STIE Gama Lumajang, 1(2), Pp.108 -118.

Anzlina, Rustam. (2013). Pengaruh Tingkat Likuiditas, Solvabilitas, Aktivitas, dan Profitabilitas Terhadap Nilai Perusahaan pada Perusahaan Real Estate dan Property di BEI Tahun 2006 - 2008. Jurnal Ekonomi, 16(2), Pp.67 75 .

Brigham dan Houston. (2013).Dasar - Dasar Manajemen Keuangan. Edisi 11 buku 2, Jakarta: Salemba Empat.

Cheng, Ming-Chang dan Tzeng Zuwei-Ching. (2011). The Effect of Leverageon Firm Value and How The Firm Financial Quality Influence on This Effect. World Journal Of Management, 3(2), Pp. 30-53.

Gregory N, Mankiw. (2012). Pengantar Ekonomi Makro. Jakarta: Salemba Empat. 
Hanafi, mamduh M dan Abdul Halim. (2005). Analisis Laporan Keuangan. Edisi Kedua. Yogyakarta: STIE YKPN.

Hanafi, Mamduh M. (2011).ManajemenKeuangan. Yogyakarta:BPFE.

Hamidah, Hartini, Umi Mardiyati. (2015). Pengaruh Inflasi, Suku Bunga Bi, Profitabilitas, Dan Risiko Finansial Terhadap Nilai Perusahaan Sektor Properti Tahun 2011-2013. Jurnal Riset Manajemen Sains Indonesia (JRMS), 6(1),Pp.395 - 416.

Herawati, Titin. (2013). Pengaruh Kebijakan Deviden, Kebijakan Hutang dan Profitabilitas terhadap Nilai Perusahaan. Jurnal Universitas Negeri Padang, 2(2), Pp.1-18.

Husna Suad dan Enny Pudjiastuti. (2013). Dasar - dasar manajemen keuangan edisi kelima, Yogyakarta : UPP STIM YKPN.

Ikbal, Muhamad. Sutrisno. Ali Djamburi. (2011). Pengaruh Profitabilitas dan Kepemilikan Insider Terhadap Nilai Perusahaan Dengan Kebijakan Hutang dan Kebijakan Deviden sebagai Variabel Intervening. Simposium Nasional Akuntasi XIV.Aceh.

Indah Sari R.S, Maswar Patuh Priyadi. (2016). Pengaruh Leverage, Profitabilitas, Size dan Growth Oportunity Terhadap Nilai Perusahaan.STIESIA. Jurnal Ilmu dan Riset Manajemen, 5(1), Pp.1-16

Jogiyanto Hartono. (2013). "Teori Portofolio dan Analisis Investasi", BPFE Yogyakarta, Edisi Kedelapan, Yogyakarta.

Kasmir. (2013). Analisis Laporan Keuangan. PT. Raja Grafindo. Jakarta.

Khumairoh, Kalbuana, Mulyati. (2015) .Pengaruh Leverage, Profitabilitas danUkuran Perusahaan Terhadap Nilai Perusahaan. Syariah Paper Accounting FEB UMS, 4(2), Pp.71 - 81 .

Kodongo Odongo, Mokoteli, LN Maina. (2014). Capital Structure, Profitability and Firm Value: Panel Evidance of Listed Firms in Kenya.MPRA Paper No. 57116, 17(1), Pp.1 - 19.

Kusumawati. (2005). Analisis Pengaruh Profitabilitas (ROE), Ukuran Perusahaan (Size) dan Leverage Keuangan Solvabilitas terhadap Tingkat Underpricing pada Perusahaan Perdana (Initial Public Offering/IPO) di Bursa Efek Jakarta,Utilitas, 13(1),Pp.93-110.

Mahendra, DJ. (2011). Pengaruh Kinerja Keuangan Terhadap Nilai Perusahaan Pada Perusahaan Manufaktur di Bursa Efek Indonesia. Jurnal Manajemen, Strategi Bisnis dan Kewirausahaan, 6(2), Pp.130 - 138.

Maryani. (2016). Pengaruh Likuiditas, Profitabilitas, Kebijakan Deviden, Kebijakan Hutang, Kepemilikan Manajerial Terhadap Nilai Perusahaan 
Pada Perusahaan Manufaktur yang terdaftar di Bursa Efek Indonesia Tahun 2010 - 2013, Jurnal Akuntansi. Universitas Maritim Raja Haji, Pp 24-40.

Matraves, Rodriguez. (2005). Profitability, Diversification, and Multinationality inLeading German and UK Firms. International Journal of Business and Economic, 4(2), Pp.87-105.

Merindha. (2016). Pengaruh Inflasi dan Profitabilitas Terhadap Nilai Perusahaan. Juenal ilmu dan Riset Akuntansi, 5(12), Pp.1 - 17.

Mulyani Sri, D Amboningtyas, A Fathony. (2017).The Influence of liquidity, profitability, leverage on firm value with capital structure as intervening variable (In Plantation Sub Sector Company 2012 - 2016 Listed In BEI). Jurnal Unpad.ac.id, 3(3), Pp.1 - 11.

Noerirawan, Abdul Muid. (2012) .Pengaruh Faktor Internal Dan Eksternal Perusahaan Terhadap Nilai Perusahaan (Studi Empiris Pada Perusahaan Manufaktur Yang Terdaftar Di Bursa Efek Indonesia Periode 2007-2010). Diponegoro Journal Of Accounting, 1(12), Pp.1 - 12.

Nopirin.(2010). Ekonomi Moneter Buku I Edisi 4. Yogyakarta: BPFE.

Pakpahan, Rosman. (2011). Pengaruh Faktor - Faktor Pundamental Perusahaan dan Kebijakan Deviden Terhadap Nilai Perusahaan. Jurnal Ekonomi, Keuangan, Perbankan dan akuntansi, 2(2), Pp.211 -217.

Pasaribu, Rowland. (2008). Pengaruh Faktor Fundamental Terhadap Harga Saham Perusahaan Go Public di Bursa Efek Indonesia (BEI) Periode 2003 - 2006. Jurnal Ekonomi dan Bisnis, 2(2), Pp.101 -113.

Prisilia Rompas, Gisela. (2013). Likuiditas, Solvabilitas, dan Rentabilitas terhadap Nilai Perusahaan BUMN yang terdaftar di Bursa Efek Indonesia.Jurnal EMBA, 1(3), Pp.252-262.

Putra adi, Lestari Vivi. (2016). Pengaruh Kebijakan Deviden, Likuiditas, Profitabilitas dan Ukuran Perusahaan Terhadap Nilai Perusahaan, E Jurnal Manajemen Unud, 5(7). Pp.4044-4070.

Putra, Eka Maharto, Putu Kepramareni dan Ni Gede Novitasari. (2016). Pengaruh Kinerja Keuangan, Inflasi Dan Tingkat Suku Bunga Terhadap Nilai Perusahaan.LPPM UNMAS Denpasar. Pp. 569 - 579.

Purnomo, Tri Hendra dan Nurul. (2013).Pengaruh Nilai Tukar, Suku Bunga dan Inflasi Terhadap Return Saham Pada Perusahaan Properti. Jurnal Ilmu dan Riset Manajemen, 2(10), Pp.1 - 20.

Purwanto, Agustin. (2017). Financial Performance Towards Value to Firms in Basic and Chemical Industry. European Research Jurnal, 20(2), Pp.443 460. 
Rahardja, Prathama. Manurung, Mandala. (2006). Teori Ekonomi Mikro Suatu Pengantar, Edisi Ketiga, Jakarta; Lembaga Penerbit Fakultas Ekonomi Universitas Indonesia.

Rompas, Gisela. (2013). Likuiditas, Solvabilitas, dan Rentabilitas Terhadap Nilai Perusahaan BUMN yang Terdaftar Di Bursa Efek Indonesia. Jurnal EMBA, 1(3), Pp.252-262.

Saidi. (2004). Faktor - Faktor yang Mempengaruhi Struktur Modal pada Perusahaan Manufaktur Go Public di BEI Tahun 1997-2002. Jurnal Bisnis dan Ekonomi, 11(1), Pp. 44 -58.

Saini, Sharma. (2009). Liquidity, Risk, and Profitability Analisis: A Case Study of Steel Aouthority of India Limited. ASBM Journal Management, 2(2), Pp. 64-74.

Sambora, Handayani, Rahayu. (2014). Pengaruh Leverage dan Profitabilitas Terhadap Nilai Perusahaan.Jurnal Administrasi Bisnis, 8(1), Pp.1-10.

Siahaan, Fadjar OP. (2011). Pengaruh Kebijakan Hutang dan Investasi Terhadap Nilai Perusahaan. Jurnal Universitas Airlangga, 2(2), Pp. 1 - 12.

Sudana, I Made. (2011). Manajemen Keuangan Perusahaan Teori dan Praktek, Jakarta: Erlangga.

Sucipto. (2003).’Penilaian Kinerja Keuangan”, Jurnal Akuntansi, Universitas Sumatra Utara, Medan, Pp. 1 - 12.

Sudiyatno, Bambang. (2012).The Company's Policy, Firm Performance, and Firm Value: An Empirical Research on Indonesia Stock Exchange. American International Journal of Contemporary Research, 2(12), Pp. 30 - 40.

Suramaya. (2012). Pengaruh Inflasi, Suku Bunga, Kurs dan Pertumbuhan PDB terhadap Indeks Harga Saham Gabungan. Jurnal Economia, 8(1), Pp.5364.

Susanti, Rika. (2010). Analisis Faktor - faktor yang Berpengaruh Terhadap Nilai Perusahaan (Study kasus pada Perusahaan Go Public yang Listed Tahun2005 -2008). Skripsi, Universitas Diponegoro, Semarang.

Susilowati, Yeye. (2011). Reaksi Signal RasioProfitabilitas dan Rasio Solvabilitas terhadap Return Saham Perusahaan. Dinamika Keuangan dan Perbankan, 3(1), Pp.17-37.

Soliha, E., Taswan. (2002). Pengaruh Kebijakan Hutang Terhadap Nilai Perusahaan Serta Beberapa Faktor Yang Mempengaruhinya. Jurnal Bisnis dan Ekonomi, 9(2), Pp.149-163.

Taurisina Firnanda dan Hening Widi Oetomo. (2016). Analisis Likuiditas, Profitabilitas, Solvabilitas dan Perputaran Persediaan Terhadap Nilai Perusahaan. Jurnal Ilmu dan Riset Manajemen, 5(2), Pp.1 - 15. 
Weston J. Freddan, Thomas E, Copeland. (2010). Manajemen Keuangan: Jilid 2, Penerbit Erlanga, Jakarta.

Wiagustini, Ni Luh Putu. (2010). Dasar - dasar Manajemen Keuangan. Cetakan Pertama. Denpasar: Udayana University Press.

Wijaya Bayu dan Panji Sedana. (2015). Pengaruh profitabilitas terhadap nilai perusahaan (kebijakan deviden dan kesempatan investasi sebagai variabel moderating). E-journal manajemenUnud, 4(12), Pp.4477 - 4500.

Winarto, Jacinta. (2015). The Determinants of Manufacturer Firm Value in Indonesia Stock Exchange, International Journal of Information, Business and Management, 17(4), Pp.323 - 349.

Witha Dwipartha, Ni Made. (2012). Pengaruh Faktor Ekonomi Makro dan Kinerja Keuangan Terhadap Nilai Perusahaan Manufaktur di Bursa Efek Indonesia. E-journal Unud, 2(4), Pp.226 - 248. 